\title{
Phytoplankton yield changes after enrichment in microcosm experiments: Applications for predicting progressive eutrophication in a mesotrophic lake, South Africa
}

\author{
P. J. Oberholster ${ }^{1,2 \star}$, P. J. Ashton ${ }^{1}$, A. M. Botha ${ }^{3}$ and C. J. Kleynhans ${ }^{4}$ \\ ${ }^{1}$ CSIR Natural Resources and the Environment, P.O. Box 320, Stellenbosch 7599, South Africa. \\ ${ }^{2}$ Department of Paraclinical Sciences, Faculty of Veterinary Science, University of Pretoria, P/Bag X04, \\ Onderstepoort 0110, South Africa. \\ ${ }^{3}$ Department of Genetics, University of Stellenbosch, Matieland, 7601, South Africa. \\ ${ }^{4}$ DWA, Resource Quality Services, P/B X 313, Pretoria 0001, South Africa.
}

Accepted 18 April, 2012

\begin{abstract}
Established microcosms containing surface water from the mesotrophic Lake Mokolo were subjected to enrichment of different concentrations with phosphorus. The microcosms were sampled through a 20 day succession period to determine the net effects of increased concentrations of phosphorus in the water column on the phytoplankton community structure during the winter and summer seasons. A significant increase in chlorophyll a (chl-a) was observed when treatments of 30,40 and $60 \mu \mathrm{g} \mathrm{L}^{-1} \mathrm{P}$ were compared to the controls. On day zero in both the winter and summer microcosm experiments, all four phosphorus treatments had similar species diversity of phytoplankton of the specific seasoned tested (winter: Margalef index $=223$; summer: Margalef index $=347$ ). However, 13 days after the addition of 40 and $60 \mu \mathrm{g} \mathrm{L}^{-1} \mathrm{P}$, the phytoplankton community exhibited a strikingly different species richness (winter: Margalef index $=123$; summer: Margalef index $=114$ ). In the winter microcosm experiments, the green alga Scenedesmus armatus dominated the phytoplankton composition at enrichment levels of 40 and $60 \mu \mathrm{g} \mathrm{L}^{-1} \mathrm{P}$ up to day 20. The biovolume of the dinophyceae Ceratium hirundinella declined rapidly after the addition of $40 \mathrm{\mu g} \mathrm{L}^{-1} \mathrm{P}$ in the different summer microcosms. In the summer microcosms, Spondylosium secedens and Microcystis aeruginosa dominated the 40 and $60 \mu \mathrm{g}$ $L^{-1} P$ microcosm enrichment experiments.
\end{abstract}

Key words: Scenedesmus armatus, southern Hemisphere lake, enrichment, cyanobacteria, threshold phosphorus concentrations, chlorophyll a (chl-a) concentration.

\section{INTRODUCTION}

The excessive input of nutrients influences the structure and dynamics of the phytoplankton community of rivers and lakes by increasing primary production and altering species composition (De Jonge et al., 2002). Nitrogen (N) and phosphorus (P) exports from point and nonpoint sources can have profound effects upon the quality of

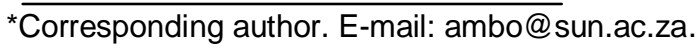

receiving streams or lakes (Correll, 1998). The degradation of water resources by eutrophication can result in losses of their component species, as well as losses of services that these systems provide (US EPA, 1996). Eutrophication is the most widespread water quality problem in the USA and many other countries (Carpenter et al., 1998). In South Africa, $58 \%$ of the reservoirs are under threat of cyanobacterial bloom formation due to eutrophication, while $11 \%$ of the major reservoirs have severe problems with cyanobacterial 
blooms due to enrichment because of anthropogenic pollution (Carpenter et al., 1998; Oberholster and Ashton, 2008). Hence, assessing the phytoplankton assemblage from a reservoir by increasing the different concentrations of phosphorus in outdoor microcosms can give possible answers to trophic changes that may occur due to anthropogenic pollution.

In addition, microcosms provide biotic simplicity, isolation and replication, all of which are necessary in determining the net effects that different stressors have on a community (Fliedner et al., 1997). Furthermore, it is difficult to document the pathways leading to changes in the structure of natural communities since environmental variables cannot be controlled. Previous studies by Brettum (1989) and Willen (2000) presented phytoplankton species as indicators at different nutrient levels for oligotrophic waters, as well as for waters with increased anthropogenic pollution. An earlier study by Lepistǿ et al. (2004) showed that anthropogenic impacts manifested as eutrophication, was reflected as changes in phytoplankton assemblages and in type-specific taxa composition. Associated with key variables (for example, $\mathrm{pH}$ and water temperature) are threshold nutrient concentrations in an aquatic system and these nutrient concentrations determine the trophic states of such a system. If an aquatic system consistently moves beyond a critical threshold (for example, above a certain maximum concentration of nutrient inputs), it may start to behave in a different way, often with unforeseen or undesirable consequences (for example, toxic cyanobacterial blooms resulting in massive fish mortalities due to a lack of dissolved oxygen). This aquatic ecosystem will now exist in a new state, also referred to as a 'regime' (Scheffer and Carpenter, 2003).

Within a new regime, the controls or feedbacks and identity (basic structure and function) of the aquatic system are different from the original (Fellows et al., 2006; Marti et al., 2004; Scheffer and Carpenter, 2003). Once such a threshold has been crossed and a regime shift has taken place, it is usually difficult to cross back or return to the previous regime, and in most cases this can only be accomplished through remediation. Therefore, an aquatic ecosystem's resilience can be determined by its relative distance from its respective pollutant threshold or guideline values (for example, total phosphorus) and their impact on the biodiversity of the aquatic system. The closer the system is located to its threshold, the smaller the required change to alter the system (for example, a sudden increase of nutrients) (Fellows et al., 2006; Marti et al., 2004; Scheffer and Carpenter, 2003). The greater the nutrient load, the more likely it is that a switch to bloom forming cyanobacteria dominance will take place. Although long-term experiments which include the whole lake ecosystem will provide perhaps the most reliable predictors, such experiments can be problematic for replication of treatment (Moss et al., 2003). A compromise, therefore, is the use of replicated microcosms. However, microcosms can not mimic the precise flushing time or turbidity expressed as the light extinction coefficient under natural lake conditions (Moss et al., 2003).

There are several studies that have empirically described changes of phytoplankton community structures and cyanobacterial biomass after enrichment in northern hemisphere temperate lakes (Correll, 1998). However, little is known about similar quantitative relationships of phytoplankton community structures in southern hemisphere temperate lakes using microcosm studies. Publications from the 1970 and 1980's (Taylor et al., 1984; Thornton and Walmsley, 1982; Walmsley and Butty, 1980; Toerien, 1977) assume implicitly or directly that phosphorus is the yield-controlling nutrient in South African man-made lakes. Therefore phosphorus was selected in the microcosm study as the major limiting nutrient.

Cyanobacterial blooms as a symptom of eutrophication have become an increasing problem in South African freshwater bodies over the last three decades (Oberholster et al., 2005a). A survey conducted by Botha and Oberholster between 2004 to 2007 in South Africa, using polymerase chain reaction (PCR) technology to distinguish toxic cyanobacteria Microcystis strains bearing the mcy genes, which correlate with their ability to synthesize the cyanobacterial biotoxin (microcystins), revealed that $99 \%$ of South Africa's major impoundments contained toxigenic strains of Microcystis (Botha and Oberholster, 2007; Oberholster and Botha, 2007). The massive proliferation of these organisms is largely caused by over nutrient enrichment (eutrophication) of water bodies, which is due to progressive increase in anthropogenic pollution (Oberholster et al., 2005b, 2008).

Cyanobacteria produce some of the most potent toxins known and antidotes are not available. These biotoxins fall into three categories namely neurotoxins, hepatotoxins and lipopolysaccharides. The biotoxins in the first two groups can produce severe reactions in animals and humans, while the third group appears to be less virulent (Oberholster et al., 2005a). However the latter have been less intensively studied. Any release of these biotoxins into surrounding water can present a significant hazard to human health and the ecosystem (Oberholster et al., 2005a). The existence of gastrointestinal disorders linked to the ingestion of cyanobacterial biotoxins, as well as the chronic risks posed by hepatotoxins make these toxins a serious threat to human health when they are present in drinking water supplies (Falconer, 2005). Thus, the objectives of the present study were; (1) to determine the different phosphorus threshold values that may cause phytoplankton composition changes in the mesotrophic Lake Moloko through the use of outdoor microcosm studies and (2) to determine the critical phosphorus threshold that will cause the aquatic system to become a 


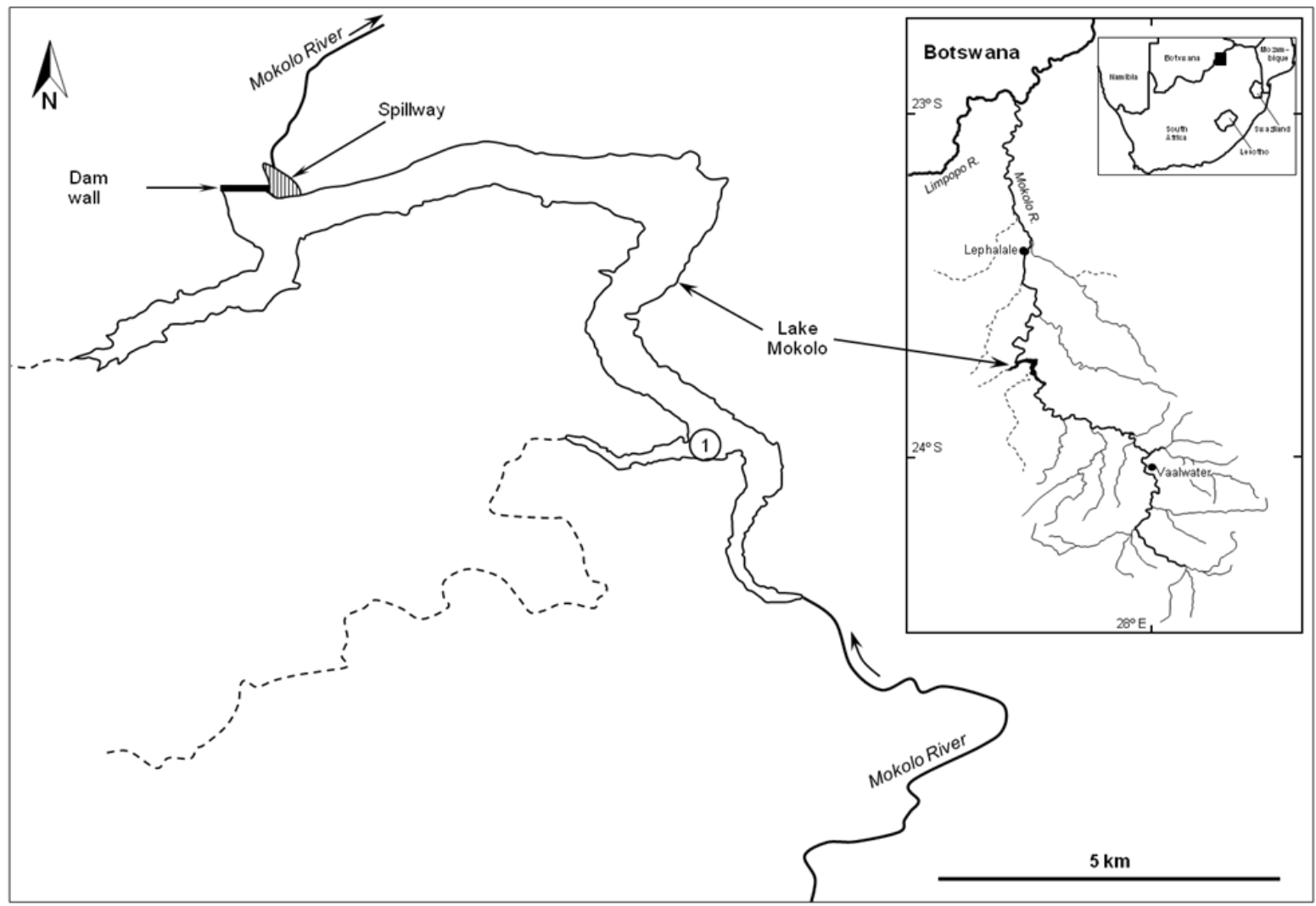

Figure 1. Map of Lake Mokolo showing the location of the sampling site, and the position of inflowing Mokolo River. Inset shows the location of the map area in South Africa.

cyanobacterial dominant system during the summer or winter months.

\section{MATERIALS AND METHODS}

\section{Background on study area}

Lake Mokolo is situated in the north-western part of the Waterberg Biosphere Reserve, approximately $50 \mathrm{~km}$ north-west of the town Vaalwater in the Limpopo Province of South Africa. The area surrounding the lake is characterized by densely wooded mountains which mainly comprise of sandstone and surrounding cliffs. Lake Mokolo was constructed in the late 1970s primarily to supply water to the Matimba coal-fired power station near the town of Lephalale, as well as for irrigation downstream of the dam wall (DWAF, 2004). An area of 4,500 ha was proclaimed as a provincial nature reserve in 1993. The reservoir is fed by the Mokolo River and has an area of 914 ha and a volume of $145.0 \mathrm{Mm}^{3}$ at full supply capacity (Figure 1). Mean annual rainfall is relatively low $(560 \mathrm{~mm}$ year $^{-1}$ ) and most rainfall is received as thunderstorms during the austral summer months (Oberholster et al., 2010). High annual average rates of evaporation $\left(1,900 \mathrm{~mm}_{\text {year }}{ }^{-1}\right)$ exceed rainfall and the area is considered to be arid (Schulze, 1997).

In the light of abundance of mineral resources in the Limpopo Valley, the mining sector and coal mining in particular, promises to become a strong economic driver in the area. South Africa produces an average of 224 million tonnes of marketable coal annually of which $25 \%$ is exported and $53 \%$ is used for electricity generation. In the face of severe power shortages, during 2007, South Africa's state-owned utility, Eskom awarded contracts for the construction of the Medupi coal fired plant in the Lephalala area within the Limpopo Province in South Africa (Fouilloux and Otto, 2009). Although the Waterberg coalfield was discovered back in the 1920 s, it was always too far from the economic heartland of the country to justify further development. However, faced with the looming electricity crisis and with enough coal for the next 150 to 200 years to supply eight power stations, the region is set for dramatic change (Creamer, 2009). With these future developments, a projected continuing in-migration of people to this area will lead to increasing urbanization in coming years. Associated with urbanization, an increase in point and non point source pollution will play an important role in progressive eutrophication of the water of Lake Mokolo which is the main reservoir in this river system. Although point source discharges (sewage treatment works) are usually controllable, diffuse (for example agriculture) and atmospheric sources (coal-fired plants) in the study area will be more difficult to control in the future (Whithers and Jarvie, 2008).

\section{Water quality parameters of Lake Mokolo}

Two sampling trips were undertaken, namely during winter (July 2009) and during summer (November 2009). Surface water (0 $>20 \mathrm{~cm}$ depth) from the lake for the outdoor microcosm experiments were collected in $25 \mathrm{~L}$ plastic containers at a 
Table 1. The average combined bottom sediment characteristics and physicalchemical parameters (mean \pm standard deviation) of water collected for the microcosm experiment in summer and winter from Lake Moloko $(n=2)$.

\begin{tabular}{|c|c|}
\hline Bottom sediment sample & Sediment (0 to $5 \mathrm{~cm}$ depth) \\
\hline \multicolumn{2}{|l|}{ Particle diameter $(\mu \mathrm{M}$} \\
\hline Sand & 220 to 231 \\
\hline Silt & 32 to 45 \\
\hline Clay & 1 to 3 \\
\hline $\mathrm{pH}$ & 8.7 \\
\hline Organic matter (\% dry weight) & $2.65 \pm 0.40$ \\
\hline Total nitrogen $\left(\mathrm{mg} \mathrm{kg}^{-1}\right)$ & $187 \pm 11$ \\
\hline Total phosphorus $\left(\mathrm{mg} \mathrm{kg}^{-1}\right)$ & $1.67 \pm 0.32$ \\
\hline \multicolumn{2}{|l|}{ Water chemistry samples } \\
\hline Potassium $\left(\mathrm{K}, \mathrm{mg} \mathrm{L}^{-1}\right)$ & $1.0 \pm 0.5$ \\
\hline Sodium $\left(\mathrm{Na}, \mathrm{mg} \mathrm{L}^{-1}\right)$ & $4.0 \pm 1.0$ \\
\hline Calcium $\left(\mathrm{Ca}, \mathrm{mg} \mathrm{L}^{-1}\right)$ & $2.2 \pm 0.72$ \\
\hline Magnesium (Mg, mg L ${ }^{-1}$ ) & $1.41 \pm 1.0$ \\
\hline Ammonia $\left(\mathrm{N}, \mathrm{mg} \mathrm{L}^{-1}\right)$ & $0.072 \pm 0.030$ \\
\hline Sulphate $\left(\mathrm{SO}_{4}, \mathrm{mg} \mathrm{L}^{-1}\right)$ & $5 \pm 1.3$ \\
\hline Chloride $\left(\mathrm{Cl}, \mathrm{mg} \mathrm{L}^{-1}\right)$ & $5.1 \pm 0.9$ \\
\hline Alkalinity $\left(\mathrm{CaCO}_{3}, \mathrm{mg} \mathrm{L}^{-1}\right)$ & $15.5 \pm 3$ \\
\hline Total phosphate $\left(P, \mu g L^{-1}\right)$ & $26.6 \pm 2$ \\
\hline Total nitrogen $\left(\mathrm{N}, \mu \mathrm{g} \mathrm{L}^{-1}\right.$ & $354 \pm 21$ \\
\hline Fluoride $\left(F, \mathrm{mg} \mathrm{L}^{-1}\right)$ & $0.07 \pm 0.02$ \\
\hline Silica $\left(\mathrm{Si}, \mathrm{mg} \mathrm{L}^{-1}\right)$ & $2.63 \pm 2.1$ \\
\hline Conductivity $\mathrm{mSm}^{-1}\left(25^{\circ} \mathrm{C}\right)$ & $5.5 \pm 1.1$ \\
\hline $\mathrm{pH}\left(25^{\circ} \mathrm{C}\right)$ & $7.9 \pm 3.0$ \\
\hline Total dissolved solids (Calc) $\left(\mathrm{mg} \mathrm{L}^{-1}\right)$ & $35 \pm 9.0$ \\
\hline Hardness $\left(\mathrm{CaCO}_{3}, \mathrm{mg} \mathrm{L}^{-1}\right)$ & $11 \pm 2.0$ \\
\hline Aluminium (Al, mg L'-1) & $0.010 \pm 0.002$ \\
\hline Cadmium $\left(\mathrm{Cd}, \mathrm{mg} \mathrm{L}^{-1}\right)$ & $0.011 \pm 0.001$ \\
\hline Iron $\left(\mathrm{Fe}, \mathrm{mg} \mathrm{L}^{-1}\right)$ & $0.020 \pm 0.010$ \\
\hline Manganese $\left(\mathrm{Mn}, \mathrm{mg} \mathrm{L}^{-1}\right)$ & $0.009 \pm 0.001$ \\
\hline Zinc $\left(\mathrm{Zn}, \mathrm{mg} \mathrm{L}^{-1}\right)$ & $0.010 \pm 0.001$ \\
\hline
\end{tabular}

permanent sampling station ( $\left.23^{\circ} 96^{\prime} 93.6^{\prime \prime} \mathrm{S}, 27^{\circ} 72^{\prime} 66.7^{\prime \prime} \mathrm{E}\right)$ in the littoral zone of Lake Mokolo. These plastic containers were transported to the premises of the Council of Scientific and Industrial Research where the outdoor microcosms were set up. During the winter and summer months, surface water and sediment were collected from Lake Mokolo for these different sets of outdoor microcosms.

The categorization of the trophic states of Lake Mokolo was based on the classification of Carlson (1977). Freshwater lakes all over the world exists from eutrophic (rich in nutrients), to oligotrophic (low nutrient levels), while intermediate states also exist for example, mesotrophic. In general, the amount of chlorophyll a (chl-a), cell density, transparency as an indicator of phytoplankton biomass and/or type of algal species present can be useful indicators of the trophic status of lakes, so long no toxic compounds that inhibit algal growth are present. However, other factors that also needs to be taken into account for microcosms are temperature and pH (Premazzi and Chiaudani, 1992).

\section{Phosphorus enrichment and time scale}

During the set-up of the outdoor microcosm experiments, care was taken to closely match the ambient conditions measured at the sampling location during the winter and summer season in Lake Mokolo to determine the physical and chemical characteristics of the bottom sediment. Bottom sediment was collected at the same place as water samples ( $0.5 \mathrm{~m}$ depth) in the littoral zone of Lake Mokolo with a grab sampler for use as bottom sediment in the different microcosms. Sediment samples $(250 \mathrm{~g})$ were dried to constant weight $\left(105^{\circ} \mathrm{C}\right)$, cooled and sieved to obtain particle size, while organic matter content was determined gravimetrically from50 $\mathrm{g}$ test portions of un-sieved material after ashing at $500^{\circ} \mathrm{C}$ for $8 \mathrm{~h}$. The physical-chemical data of the bottom sediment and surface water column of Lake Molopo used in the microcosm study are given in Table 1.

The outdoor microcosms were set up on the premises of the Council of Scientific and Industrial Research in triplicate glass 
aquariums containing $10 \mathrm{~L}$ of lake water and $1 \mathrm{~kg} /$ wet weight bottom sediment from the littoral zone of Lake Mokolo. Separate sets of outdoor microcosms were set up for the winter and summer months to mimic the environmental variables, for example, temperature, day length and rainfall of each specific season. After the bottom sediment was spread evenly on the bottom of each microcosm, $10 \mathrm{~L}$ of lake water (collected in winter and summer) was pored gently through a glass tube into each microcosm. All microcosms were left for one week to stabilize after which a subsample of $1 \mathrm{~L}$ water was taken for chemical and phytoplankton composition analyses.

Four $\mathrm{P}$ enrichment levels were set by adding a final concentration of $20,30,40$ and $60 \mu \mathrm{g} \mathrm{L}^{-1} \mathrm{P}\left(\mathrm{NaH}_{2} \mathrm{PO}_{4}\right)$ to each microcosm in triplicate containing winter or summer phytoplankton depending on season. Microcosms with no added nutrients served as nutrient controls. To ensure that $\mathrm{P}$ remained as limiting nutrient in the microcosm, inorganic $\mathrm{N}$ (as $\mathrm{NH}_{4} \mathrm{NO}_{3}$ ) was added to the microcosms to reach a $\mathrm{N}: \mathrm{P}$ molar ratio of 30 based on $\mathrm{P}$ concentrations measured the day before starting the experiment. Each microcosm was gently mixed by aeration (20 air bubbles per minute) and sampled five times for each $P$ enrichment (day 0 , three, six, 13 and 20). We decided on these sampling intervals since most field observations show more than one to three dominant species at any phase of seasonal development as predicted by the competitive exclusion theory of Hardin (1960). The reasons are found in the different responses of phytoplankton to the frequency of disturbances or changes in abiotic resource conditions at different scales (Reynolds, 1984). These different scales are: (1) shorter than one generation time induces physiological responses, (2) frequencies between 20 and $200 \mathrm{~h}$ interact with the phytoplankton growth rate, and (3) disturbances at up to 10-day intervals can initiate a successional sequence in phytoplankton development (Reynolds, 1984).

In addition, the total time (days) taken by a specific phytoplankton species to dominate the algal community at the different $P$ concentrations were calculated from the beginning of the experiment until $\geq 50 \%$ total algal abundance was reached. The moment of enrichment was designated as day 0 of the experiment and all changes were related to conditions immediately after this time. Water losses due to evaporation and sub-sampling for phytoplankton identification were replaced by deionized water throughout the duration of the experiment. An average of $250 \mathrm{ml}$ water of each $10 \mathrm{~L}$ microcosm was replaced by deionized water over the study period of 20 days.

\section{Phytoplankton community analyses}

Species composition and community structure before and after enrichment with different concentrations of $P$ were assessed from $50 \mathrm{ml}$ aliquots sampled from each microcosm, then fixed with buffered $5 \%(\mathrm{v} / \mathrm{v})$ formaldehyde. Phytoplankton cells were identified and counted from transects in a $1 \mathrm{ml}$ Sedgewick-Rafter sedimentation chamber. All identifications were made by using a compound microscope with 1,250 x magnification (Truter, 1987; Van Vuuren et al., 2006). Strip counts were made until at least 300 individuals with protoplasm of each of the dominant phytoplankton species were counted. Algae abundance in the samples was evaluated by counting the presence of each species as cells in a filament or equal number of individual cells. Additional aliquots from each algal sub-sample were removed for diatom identification (Taylor et al., 2007). Diatom frustules were cleaned with concentrated $\mathrm{H}_{2} \mathrm{SO}_{4}$ and $\mathrm{K}_{2} \mathrm{Cr}_{2} \mathrm{O}_{7}$ to facilitate accurate identification (Patrick and Reimer, 1966). Algal biovolume was calculated by measuring the corresponding dimensions using the geometric formulas given by Willen (1976). Diversity $\left(d_{s}\right)$ was calculated, as described in Margalef (1979), by computing the equation $d_{s}=(s-$ $1) / \log N$; where $s$ is the number of species and $N$ is the number of individuals. Species richness was determined by using the number of different taxonomic units that could be identified within 300 cells from each sample.

\section{Physicochemical and chl-a parameter}

Nutrients [total nitrogen (TN) and total phosphorus (TP)] were analyzed in the water column of each outdoor microcosm before enrichment with the different concentrations of $P$, using the spectrophotometric method according to the procedures published by the American Public Health Association, American Water Works Association, and Water Pollution Control Federation (1980). Water temperature, $\mathrm{pH}$, dissolved oxygen and electrical conductivity were measured with a Hach Sension ${ }^{\mathrm{TM}} 156$ portable multiparameter (Loveland, USA). Water transparency was measured with a $25 \mathrm{~cm}$ Secchi disk with black and white quadrants.

Chl- $a$ was measured spectrophotometrically at 664 and $750 \mathrm{~nm}$, respectively and calculated according to Porra et al. (1989). In brief, sub-samples for chl-a were filtered onto glass fiber filters $(1.0 \mu \mathrm{M}$ average pore size). Chl-a was removed from each filter by leaching in cold $\left(4^{\circ} \mathrm{C}\right)$, buffered $90 \%(\mathrm{v} / \mathrm{v})$ acetone for $18 \mathrm{~h}$ under subdued lighting, after which chl-a were measured. We calculated mean and standard error for each treatment followed by Tukey's multiple comparisons of the means to check for differences between the treatments and the controls $(P \leq 0.05)$ using the SYSTAT $\AA 7.0 .1$ software package (SYSTAT, 1997).

\section{RESULTS}

The application of the Carlson (1977) trophic state index to data collected during the winter and summer water collection trips showed that Lake Mokolo was oligotrophic in terms of chl-a measurements, but mesotrophic in terms of $\mathrm{P}$ levels. No significant changes in phytoplankton composition and chl-a concentration were observed between the controls and the addition of $20 \mathrm{\mu g} \mathrm{L}^{-1} \mathrm{P}$ in the different winter and summer microcosm experiments (Tables 3 and 4). Post-enrichment with $P$ in these experiments were associated with several small-celled species, such as Dinobryon divergens and Oocystis rupestris. These phytoplankton species compositions agree with observations of an assemblage typical for oligo-mesotrophic waters except for the occurrence of Ceratium hirundinella. The median of chl-a in the winter and summer microcosm experiments after the addition of $20 \mu \mathrm{g} \mathrm{L}^{-1} \mathrm{P}$ was 2.6 and $3.1 \mathrm{\mu g} \mathrm{L}^{-1}$, respectively. The blue-green algae group Cyanophyceae contributed $6 \%$ to the post enrichment total biovolume in winter and $8 \%$ in summer, while the proportion of diatom (Bacillariophyceae) biovolume were $42 \%$ at a concentration of $20 \mathrm{\mu g} \mathrm{L}^{-1} \mathrm{P}$ in the winter microcosm (Table 2 and Figure 2).

A positive correlation $(P \leq 0.05)$ between an increase in chl- $a$ and the addition of $30 \mu \mathrm{g} \mathrm{L}^{-1} \mathrm{P}$ was observed in both the winter and summer microcosm experiments. In the 
Table 2. Changes in mean seasonal (winter and summer) biovolume of major algal groups $\left(\mu \mathrm{m}^{3} \mathrm{ml}^{-1} \times 10^{3}\right)$ after postenrichment with $40 \mu \mathrm{g} \mathrm{L}^{1} \mathrm{P}$ over a period of 20 days.

\begin{tabular}{lcccccccc}
\hline \multirow{2}{*}{ Post-enrichment with $\mathbf{4 0} \mathbf{\mu g L}^{-1} \mathbf{P}$} & \multicolumn{3}{c}{ Winter } & & \multicolumn{3}{c}{ Summer } \\
\cline { 2 - 3 } \cline { 6 - 8 } & Mean & SD & $\%$ & & Mean & SD & $\%$ \\
\hline Algal group & & & & & & & \\
Chlorophyceae & 7560 & 1260 & 51 & & 421 & 137 & 10.1 \\
Bacillariophyceae & 5430 & 860 & 43 & & 628 & 128 & 17.1 \\
Chrysophyceae & 28 & 9 & 0.6 & & 219 & 36 & 1.1 \\
Cryptophyceae & 1,7 & 0.81 & 0.03 & & 39 & 7 & 0.7 \\
Cyanophyceae & 1.61 & 0.76 & 0.02 & & 8670 & 1410 & 55.1 \\
Dinophyceae & 29 & 8.8 & & 0.2 & & 563 & 111 & 14.5 \\
Euglenophyceae & 311 & 81 & 2.1 & & 493 & 87 & 11.2 \\
\hline
\end{tabular}

The standard deviation (SD) and percentage composition (\%) for winter and summer are indicated.

different winter microcosms, the phytoplankton biovolume was dominated by the green algae species Scenedesmus armatus (27\%) and the diatom Melosira varians (33\%) after the addition of $30 \mathrm{\mu g} \mathrm{L}^{-1} \mathrm{P}$ (Table 4 and Figure 2). The summer microcosms after postenrichment with $30 \mu \mathrm{g} \mathrm{L} \mathrm{L}^{-1} \mathrm{P}$ was dominated by Trachelomonas intermedia (32\%) and Euglena sociabilis (24\%). The median of total phytoplankton biomass as chl$a$ in the winter and summer microcosm experiments after the addition of $30 \mu \mathrm{g} \mathrm{L}^{-1} \mathrm{P}$ was 55.2 and $69.1 \mathrm{\mu g} \mathrm{L}^{-1}$, respectively. The minimum water temperature in the microcosm experiments in summer was $12^{\circ} \mathrm{C}( \pm 2)$, while the winter minimum temperature was $8^{\circ} \mathrm{C}( \pm 1)$. In the winter microcosm experiments, the green algal $S$. armatus dominated the phytoplankton composition at enrichment levels of 30,40 and $60 \mu \mathrm{g} \mathrm{L}^{-1} \mathrm{P}$ up to day 20 , while the biovolume of the algae group Bacillariophyceae with the dominant $\mathrm{N}$-heterotrophic diatom species $M$. varians increased from 11 to $23 \%$ after post-enrichment concentrations of $30 \mu \mathrm{g} \mathrm{L}^{-1} \mathrm{P}$.

Furthermore, the biovolume of the algae group Dinophyceae with $C$. hirundinella as the dominant species declined from 22 to $14.5 \%$ after the addition of 40 $\mu \mathrm{g} \mathrm{L}^{-1} \mathrm{P}$ in the different summer microcosms (Table 3 ). In the summer microcosms, the species $T$. intermedia and E. sociabilis, which dominated the phytoplankton composition at an enrichment level of $30 \mathrm{\mu g} \mathrm{L}^{-1} \mathrm{P}$ was replaced as dominant species by the desmid Spondylosium secedens and the cyanobacteria Microcystis aeruginosa in the 40 and $60 \mathrm{\mu g} \mathrm{L}^{-1} \mathrm{P}$ microcosm experiments (Table 3). The median of chl-a in the summer microcosm experiments after the addition of 40 and $60 \mu \mathrm{g} \mathrm{L} \mathrm{L}^{1} \mathrm{P}$ were 75.2 and $89.2 \mu \mathrm{g} \mathrm{L}^{-1}$, respectively. At post-enrichment concentrations of 40 and $60 \mathrm{\mu g} \mathrm{L}^{-1} \mathrm{P}$, cyanobacteria respectively contributed 55.1 and $59.4 \%$ of the total biovolume at day 20 in the summer microcosms. The dominance of cyanobacteria $\geq$ $50 \%$ was evident from day 13 to 20 in the summer microcosm experiments enriched with 40 and $60 \mu \mathrm{g} \mathrm{L}^{-1} \mathrm{P}$ (Figure 2). The proportion of diatom species (Bacillariophyceae) in the summer enrichment experiments with 40 and $60 \mu \mathrm{g} \mathrm{L}^{-1} \mathrm{P}$ were 17.1 and $14.6 \%$, respectively (Table 3 and Figure 2).

On day zero of our winter and summer microcosm experiments, all four treatments in triplicate had similar species richness of algae (winter: Margalef index = 223; summer: Margalef index $=347$ ), but 13 days after the addition of 40 and $60 \mu \mathrm{g} \mathrm{L}^{-1} \mathrm{P}$, the phytoplankton community exhibited a strikingly different species richness (winter: Margalef index $=123$; summer: Margalef index $=114)$.

\section{DISCUSSION}

From the data generated in the different outdoor microcosm experiments, it seemed that the aquatic system may reach it critical threshold for $P$ in the summer to change to a dominant cyanobacteria system with the addition of $40 \mathrm{\mu g} \mathrm{L}^{-1} \mathrm{P}$ (Table 3). Hence, although cyanobacteria showed a conspicuous stepped increase with increasing $P$ concentrations over the entire range of data sets in summer, it seems that lower water temperature may have hampered its dominancy $(\geq 50 \%)$ or prevented bloom formation in the winter microcosm experiments (Kruger and Eloff, 1978; Oberholster and Botha, 2009). Numerous studies have shown that phytoplankton taxonomic composition and species diversity changes with increasing nutrient levels (Smith, 1990; Watson et al., 1997) and that the changes can be correlated with differences amongst taxa in nutrient uptake or growth (Reynolds, 1984).

In similar microcosm experiments in which 1,000 to $4,000 \mathrm{~L}$ of water from Lake Michigan were enclosed in clear plastic bags, Schelske et al. (1974) found that when $\mathrm{P}$ was added, silica was reduced to levels that 
Table 3. Composition and changes of phytoplankton community after post-enrichment in a set of summer experimental microcosms.

\begin{tabular}{|c|c|c|c|c|c|}
\hline Division & $\begin{array}{l}\text { Major species in microcosms } \\
\text { at day } 0\end{array}$ & $\begin{array}{l}\text { Species abundance in } \\
\text { microcosms at day } 20 \\
\left(20 \mu \mathrm{g} \mathrm{L}^{-1}\right) \text { enrichment }\end{array}$ & $\begin{array}{l}\text { Species abundance in } \\
\text { microcosms at day } 20 \\
\left(30 \mu \mathrm{g} \mathrm{L}^{-1}\right) \text { enrichment }\end{array}$ & $\begin{array}{l}\text { Species abundance in } \\
\text { microcosms at day } 20 \\
\left(40 \mu \mathrm{g} \mathrm{L}^{-1}\right) \text { enrichment }\end{array}$ & $\begin{array}{l}\text { Species abundance in } \\
\text { microcosms at day } 20 \\
\left(60 \mu \mathrm{g} \mathrm{L}^{-1}\right) \text { enrichment }\end{array}$ \\
\hline \multicolumn{6}{|l|}{ Chromophyta } \\
\hline Cryptophyceae & Cryptomonas sp. & ++ & ++ & ++ & ++ \\
\hline Chrysophyceae & Dinobryon divergens & + & + & + & + \\
\hline \multirow{6}{*}{ Bacillariophyceae } & Aulacoseira muzzanensis & + & + & + & + \\
\hline & Diatoma vulgaris & ++ & ++ & ++ & +++ \\
\hline & Fragilaria ulna & ++ & ++ & +++ & +++ \\
\hline & Gomphonema affine & + & +++ & +++ & +++ \\
\hline & Pinnularia viridus & ++ & ++ & ++ & ++ \\
\hline & Melosira varians & ++ & +++ & +++ & +++ \\
\hline \multirow{2}{*}{ Dinophyceae } & Peridinium africana & +++ & +++ & +++ & +++ \\
\hline & Ceratium hirundinella & +++ & ++ & ++ & ++ \\
\hline \multicolumn{6}{|l|}{ Chlorophyta } \\
\hline \multirow{6}{*}{ Chlorophyceae } & Closterium lineatum & ++ & ++ & ++ & ++ \\
\hline & Spondylosium secedens & + & ++ & ++++ & ++++ \\
\hline & Cosmarium pseudopraemorsium & ++ & ++ & ++ & ++ \\
\hline & Chlamydomonas africana & ++ & ++ & ++ & ++ \\
\hline & Pediastrum duplix. & ++ & ++ & ++ & ++ \\
\hline & Oocystis rupestris & ++ & ++ & +++ & +++ \\
\hline \multicolumn{6}{|l|}{ Euglenophyta } \\
\hline \multirow{3}{*}{ Euglenophyceae } & Trachelomonas intermedia & +++ & ++++ & ++++ & ++++ \\
\hline & Phacus pleuronectes & ++ & +++ & ++++ & ++++ \\
\hline & Euglena sociabilis & ++ & ++ & +++ & +++ \\
\hline \multicolumn{6}{|l|}{ Cyanoprokaryota } \\
\hline \multirow{2}{*}{ Cyanophyceae } & Oscillatoria princeps & + & ++ & +++ & +++ \\
\hline & Microcystis aeruginosa & +++ & +++ & +++++ & +++++ \\
\hline
\end{tabular}

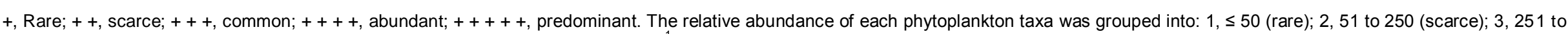
1000 (common); 4, 1001 to 5000 (abundant); 5, 5001 to 25000 (predominant) cells ${ }^{-1}$.

limited algal growth but $\mathrm{N}$ concentrations were not effected. In their study, they concluded that $P$ was the limiting nutrient in Lake Michigan, but that silica was becoming limiting for diatoms. In temperate zone lakes, oligotrophic systems supported minimal phytoplankton biomass with 
Table 4. Composition and changes of phytoplankton community after enrichment in a set of winter experimental microcosms.

\begin{tabular}{|c|c|c|c|c|c|}
\hline Division & $\begin{array}{l}\text { Major species in } \\
\text { microcosms at day } 0\end{array}$ & $\begin{array}{l}\text { Species abundance in } \\
\text { microcosms at day } 20 \\
\left(20 \mu \mathrm{g} \mathrm{L}^{-1}\right) \text { enrichment } \\
\end{array}$ & $\begin{array}{l}\text { Species abundance in } \\
\text { microcosms at day } 20 \\
\left(30 \mu \mathrm{g} \mathrm{L}^{-1}\right) \text { enrichment } \\
\end{array}$ & $\begin{array}{l}\text { Species abundance in } \\
\text { microcosms at day } 20 \text { (40 } \\
\left.\mu \mathrm{g} \mathrm{L}^{-1}\right) \text { enrichment }\end{array}$ & $\begin{array}{c}\text { Species abundance in } \\
\text { microcosms at day } 20(60 \\
\left.\mu \mathrm{g} \mathrm{L}^{-1}\right) \text { enrichment }\end{array}$ \\
\hline \multicolumn{6}{|l|}{ Chromophyta } \\
\hline Cryptophyceae & Cryptomonas sp. & ++ & ++ & ++ & ++ \\
\hline Chrysophyceae & Dinobryon divergens & ++ & ++ & ++ & ++ \\
\hline \multirow{14}{*}{ Bacillariophyceae } & Aulacoseira muzzanensis & ++ & ++ & +++ & +++ \\
\hline & Craticula cuspidate & ++ & +++ & +++ & +++ \\
\hline & Cymbella kappi & +++ & +++ & ++ & ++ \\
\hline & Diatoma vulgaris & ++ & ++ & ++ & +++ \\
\hline & Fragilaria ulna & ++ & ++ & +++ & +++ \\
\hline & Gomphonema affine & + & +++ & +++ & +++ \\
\hline & Nitzschia reversa & + & + & + & \\
\hline & Nitzschia linearis & + & +++ & +++ & +++ \\
\hline & Rhopalodia gibba & +++ & +++ & ++ & + \\
\hline & Pinnularia viridus & ++ & ++ & ++ & ++ \\
\hline & Pinnularia subcapitata & ++ & ++ & + & \\
\hline & Surirella ovalis & ++ & ++ & + & + \\
\hline & Melosira varians & +++ & +++ & +++++ & +++++ \\
\hline & Stephanodiscus hantzschii & & + & ++++ & ++++ \\
\hline \multicolumn{6}{|l|}{ Chlorophyta } \\
\hline \multirow{7}{*}{ Chlorophyceae } & Closterium lineatum & ++ & ++ & ++ & ++ \\
\hline & Spondylosium secedens & ++ & ++ & ++ & ++ \\
\hline & Cosmarium pseudopraemorsium & ++ & ++ & ++ & ++ \\
\hline & Chlamydomonas africana & ++ & ++ & ++ & ++ \\
\hline & Pediastrum diplex & & & & \\
\hline & Scenedesmus armatus & ++ & ++ & +++++ & +++++ \\
\hline & Oocystis rupestris & ++ & ++ & +++ & +++ \\
\hline \multicolumn{6}{|l|}{ Euglenophyta } \\
\hline \multirow{2}{*}{ Euglenophyceae } & Trachelomonas intermedia & +++ & +++ & +++ & +++ \\
\hline & Phacus pleuronectes & ++ & ++ & +++ & +++ \\
\hline \multicolumn{6}{|l|}{ Cyanoprokaryota } \\
\hline \multirow{2}{*}{ Cyanophyceae } & Oscillatoria princeps & ++ & ++ & +++ & +++ \\
\hline & Anabaena flos-aquae & +++ & ++ & + & + \\
\hline
\end{tabular}

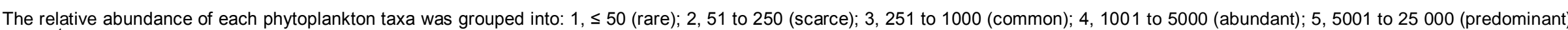
cells $\mathrm{L}^{-1} .+$, Rare; ++ , scarce; +++ , common; ++++ , abundant; +++++ , predominant. 


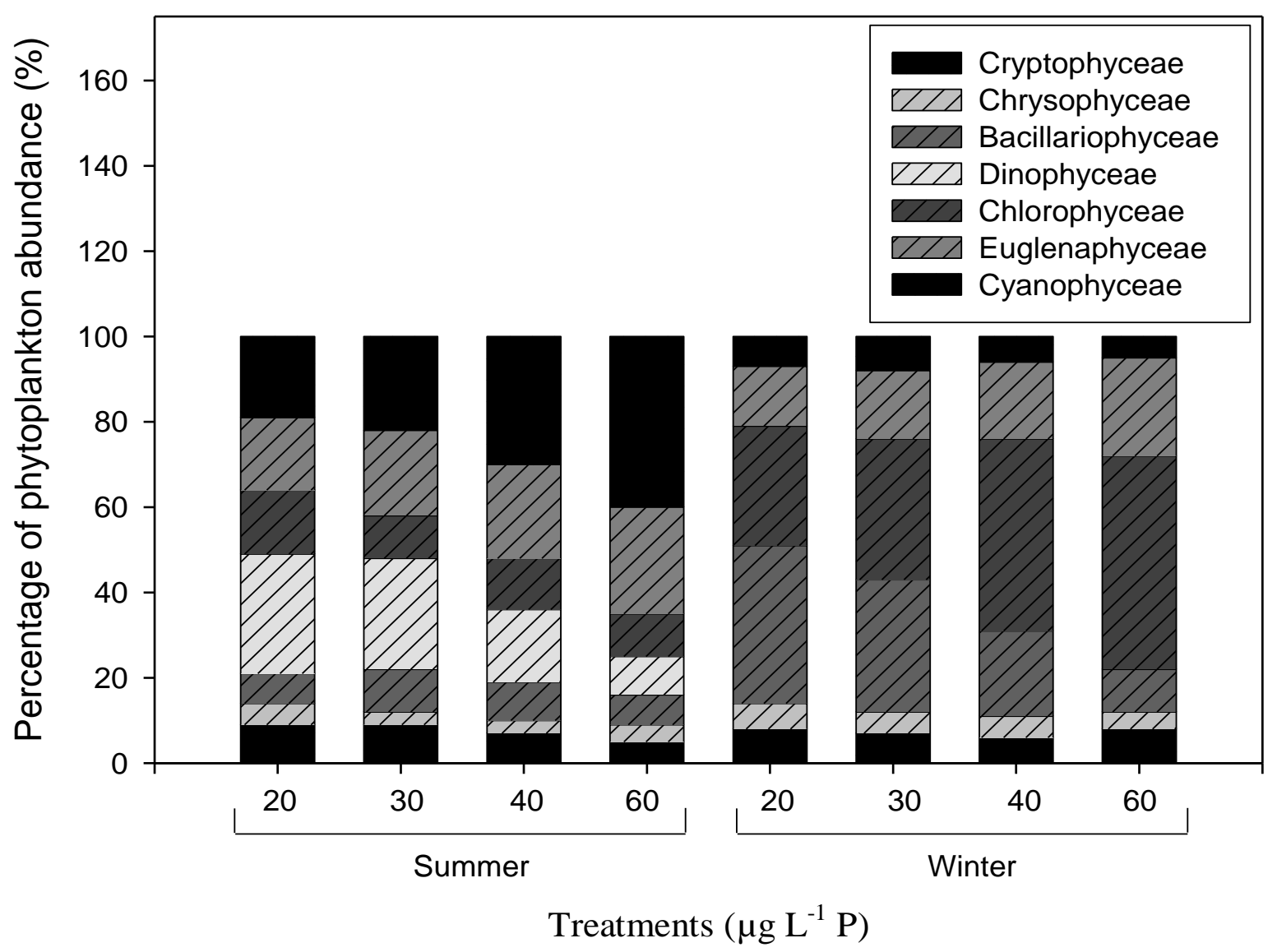

Figure 2. Percentage of phytoplankton abundance (\%) during the different summer and winter treatments of phosphorus.

low species diversity, while eutrophic and hypereutrophic lakes sustain very high average algal biomass often dominated by very few taxa, usually cyanobacteria, diatoms or in some water bodies, dinoflagellates (Jensen et al., 1994). The increase in biomass of the centric diatoms $M$. varians and Stephanodiscus hantzschii after enrichment concen-trations of 40 and $60 \mu \mathrm{g} \mathrm{L}^{-1}$ of $P$ indicates that these species were indicators of eutrophic to hypertrophic water conditions which is in association with a previous study by van Dam et al. (1994). From our study it is clear that these species typically have greater total P optima than do N-autotrophs.

The negative relationship observed in this study between the biomass of the dinophyte $C$. hirundinella which is a slow-growing inedible late summer algae and the higher tested phosphate concentrations indicate that the higher abundance of this species was associated with low concentrations $\left(30 \mu \mathrm{g} \mathrm{L}^{-1}\right)$ of $\mathrm{P}$ enrichment (Willen, 1991, 2000; Reynolds et al., 2002). Similar observations are provided by Pollingher (1988). Padisak (1985) reported that at higher concentrations of phosphorus, $C$. hirundinella abundance is suppressed by blue-green algae. This is concurrent with the observations in our summer microcosm study, where the cyanobacterial species $M$. aeruginosa did replace $C$. hirundinella to become the dominant species after enrichment concentrations of $40 \mu \mathrm{g} \mathrm{L}^{-1} \mathrm{P}$. According to a study by Watson et al. (1997), dinoflagellates have low average biomass in oligotrophic systems and increased rapidly with an increase in $P$ in meso-eutrophic lakes. This implied a threshold nutrient requirement for growth as observed in our study at a concentration of $30 \mathrm{\mu g} \mathrm{L}^{-1}$ of $P$ after which their biomass generally decline at higher concentrations of $P$.

The conspicuous stepped increase of $M$. aeruginosa with increasing $\mathrm{P}$ enrichment concen-trations over the entire data set range in the summer microcosm, can possibly be related to higher water temperatures since phosphorus recycling (number of phosphorus molecules recycled per unit time) is more intensive in warmer waters, while processes of phos-phorus release from lake sediment and mineralization are highly temperature dependent (Hamilton et al., 2001). Furthermore it is a known fact that cyanobacterial blooms usually occur during warm periods at temperatures above $20^{\circ} \mathrm{C}$ (Robarts and Zohary, 1987). 
Although diatoms are the most abundant group in oligotrophic systems and supply most of the phytoplankton biomass in lakes with low to moderate nutrient levels (10 to $30 \mathrm{mg} \mathrm{L}^{-1} \mathrm{P}$ ), they are generally subdominant to cyanobacteria in eutrophic lakes (> 100 $\left.\mu g L^{-1} P\right)$. The negative correlation observed between the decline in biomass of certain diatom species and the increase of phosphorus concentrations during the winter and summer microcosm experiments indicated that their dominance were associated with low phosphorus concentrations and that they are better competitors for phosphorus than other algae. This observation was also confirmed in laboratory studies by Smith and Kalh (1983). Their competitive superiority can be explained by the catalytic property of silica in cell walls of these specimens which act as adsorbent for low phosphorus concentrations (Werner, 1977). In our study, pennate diatoms were favoured at $20 \mu \mathrm{g} \mathrm{L}^{-1} \mathrm{P}$, while centric diatoms for example, $M$. varians with higher growth rates and lower sinking losses was favoured up to $40 \mathrm{\mu g} \mathrm{L}^{-1} \mathrm{P}$ (Corbelas and Rojo, 1994). Unlike cyanobacteria, diatoms did not show a significant change in their rate of increase with TP. It is known that the growth of diatoms can be inhibited by a low supply of silica. However, Willen (1991) reported that $\mathrm{Si}$ concentrations as low as $0.2 \mathrm{mg} \mathrm{L}^{-1}$, much lower than the concentrations measured $\left(2.5 \mathrm{mg} \mathrm{L}^{-}\right.$

$1 \mathrm{Si}$ ) in our study, should be sufficient for diatom reproduction.

According to a study by Happy-Wood (1988), Chlorophytes are a diverse group and rarely dominates temperate lake phytoplankton communities except at nutrient extremes. Nevertheless, in our study Chlorophytes dominated the phytoplankton community during the winter microcosm, suggesting that the absence of major effects of zooplankton grazing may have caused their sustained dominance. This data is not in relationship with previous lake studies of Watson et al. (1997). They showed in their study on 91 northern hemisphere temperature lakes a slight increase in Chlorophytes biomass with considerable variance at intermediate TP levels of $30 \mathrm{\mu g} \mathrm{L}^{-1}$. On the other hand, Duarte et al. (1992) found in their study that green algae was the dominate species in shallow oligotrophic Florida lakes, but that the algal assemblage of these lakes was highly diverse. In addition, a study conducted by Peterson and Stevenson (1989) on the Ohio River and six Kentucky tributaries indicated that the abundant diatom $M$. varians and the green algae $S$. armatus, that was dominant in our winter microcosm, correlated positively with lower surface water temperatures.

Moreover, chrysophytes which initially increased with increased $\mathrm{P}$ concentrations, showed a smaller average biomass at $P$ levels of 40 and $60 \mu \mathrm{g} \mathrm{L}^{-1}$. According to Caron et al. (1990), there exists a comparatively poor relationship between $\mathrm{P}$ and chrysophyte biomass, suggesting that this algal group is more influenced by factors other than phosphorus, such as $\mathrm{pH}$, alkalinity or iron. Data generated from our study indicated that species richness declines with higher nutrient loading, which is consistent with earlier studies by Reynolds (1984). It is generally accepted that the N:P ratio is an important determinant of the species composition of natural populations in lakes (Takamura et al., 1992). Studies show shifts from green algae and diatoms to blue-green algae as the N:P ratio in the lakes decrease (Schindler, 1977, 1978; Kotak et al., 2000). In Lake Hartbeespoort (South Africa), a somewhat deeper reservoir than Lake Mokolo, the absence of Microcystis aeruginosa during 1988 and 1989 was ascribed to the low epilimnetic phosphate concentration and the increasing $\mathrm{N}: \mathrm{P}$ ratios, that is from about four to 10 (Chutter, 1989). In addition to atmospheric and agriculture sources of $\mathrm{N}$ and $\mathrm{P}$ in the study area of Lake Moloko, the increase in human population density to this area will have a strong influence on the water resources downstream of the developing areas, since humans used flowing waters as convenient wastewater disposal systems (Proulx et al., 1996; Smith et al., 1997).

Furthermore, a change in the trophic states of Lake Mokolo from a mesotrophic to eutrophic state dominated by cyanobacterial blooms due to over enrichment by nutrients can have detrimental effects for irrigation farmers downstream of Lake Mokolo. The exposure of edible crop plants to cyanobacterial toxins may cause these toxins to accumulate in plant tissues (Codd et al., 1999). The introduction of these toxins into the human food chain is therefore a strong possibility, which may pose great concern for human health if these crops were ingested. However whether spray irrigation promotes cyanobacterial biotoxin release on crops due to cell breakdown via sheer stress, is not yet known. At this stage strong evidence exist that cyanobacterial biotoxins inhibited the germination of pollen which could have an adverse effect on crop yield (Metcalf et al., 2004).

\section{Conclusion}

From our study it is evident that in order to predict the effects of $P$ inputs on receiving reservoir waters and phytoplankton community structure of Lake Mokolo, it is necessary to be able to predict how water body $\mathrm{P}$ concentrations and phytoplankton community structure vary as the external anthropogenic inputs change over time. Moreover, our study indicated that the critical threshold loading value for a southern hemisphere temperate mesotrophic lake is reached with an increase of $40 \mu \mathrm{g} \mathrm{L}^{-1} \mathrm{P}$ in winter and $30 \mu \mathrm{g} \mathrm{L}^{-1} \mathrm{P}$ in summer, and that beyond these thresholds any additional $P$ inputs will cause significant changes in phytoplankton diversity. The data generated in this study can play an important role in managing progressive eutrophication in southern 
hemisphere temperate mesotrophic lakes.

\section{REFERENCES}

American Public Health Association (APHA), American Water Works Association (AWWA), and Water Pollution Control Federation (WPCF)., 1992. In: Standard Methods for the Examination of Water and Wastewater. (19 ${ }^{\text {th }}$ edition). APHA, AWWA, and WPCF, Washington, D.C., USA.

APHA (1998). Chlorophyll. in: APHA (Eds.), Standard Methods for the Examination of Water and Wastwater, $20^{\text {th }}$ ed. American Public Association, Washington, DC, pp. 10.18-10.25.

Botha AM, Oberholster PJ (2007). PCR-Based Markers for Detection and Identification of Toxic Cyanobacteria. WRC Report No. K5/1502/01/07. Water Research Commission, Pretoria, South Africa, pp. 1-70.

Brettum P (1989). Algae as indicators of water quality in Norwegian lakes. Phytoplankton. Niva-Rapport, 0-86116, pp. 100-111.

Carlson RE (1977). A trophic state index for lakes. Limnol. Oceanogr. 22:361-369.

Caron DA, Porter KG, Sanders RW (1990). Carbon, nitrogen and phosphorus budgets for the mixotrophic phytoflagellate Poterioochromonas malhamensis (Chrysophyceae) during bacterial ingestion. Limnol. Oceanogr. 35:433-444.

Carpenter SR, Caraco NF, Correll DL, Howarth RW, Sharpley AN, Smith VH (1998). Nonpoint pollution of surface waters with phosphorus and nitrogen. Ecol. Appl. 8:559-568.

Chutter FM (1989). Evaluation of the impact of the $1 \mathrm{mg} \mathrm{I}^{-1}$ PhosphateP. Standard on the water quality and trophic state of Hartbeespoort Dam. Contract report to the Water Research Commission, WRC Report No. 181/1/89 Pretoria South Africa.

Codd GA., Metcalf JS., Beattie KA (1999). Retention of Microcystis aeruginosa and microcystin by salad lettuce after spray irrigation with water containing cyanobacteria. Toxicon 37:1181-1185.

Corbelas M, Rojo C (1994). Factors influencing the share of planktic diatoms in lakes. Algo. Stud. 74:73-104.

Correll DL (1998). The role of phosphorus in the eutrophication of receiving waters: a review. J. Environ. Qual. 27:261-266.

Creamer M (2009). ESKOM spearheads largest build programme in SA. Eng. News Mining Wkly. pp. 25-28.

De Jonge VN, Elliot M, Orive E (2002). Causes, historical development, effects and future challenges of a common environmental problem: eutrophication. Hydrobiology 475:1-19.

Duarte CM, Agusti S, Canfield DE (1992). Patterns in phytoplankton community structure in Florida lakes. Limnol. Oceanogr. 37:155-161.

DWAF (2004). Internal Strategic Perspective: Limpopo Water Management Area : Prepared by Goba Moahloli Keeve Steyn (Pty) Ltd, in association with Tlou \& Matji (Pty) Ltd and Golder Associates (Pty) Ltd. on behalf of the Directorate: National Water Resource Planning. Report No. P WMA 01/000/00/0304.

Falconer IR (2005). Cyanobacterial Toxins of Drinking Water Supplies: Cylindrospermopsins and Microcystins. CRC Press, Florida, USA. pp. 100-279.

Fellows CS, Valett HM, Dahm CN, Mulholland PJ, Thomas SA (2006). Coupling nutrient uptake and energy flow in headwater streams. Ecosystem 9:788-804.

Fliedner A, Remde A, Niemann R, Schafers C, (1997). Effects of organotin pesticide azocyclotin in aquatic microcosms. Chemosphere 35:209-222.

Fouilloux JP, Otto M (2009). Medupi and Kusile: supercritical giants of South Africa. Modern Power Syst. pp. 13-23.

Hamilton DP, Spillman C, Prescott KL, Kratz TK, Magnuson JJ (2001). Effects of atmospheric nutrient input on trophic status of Crystal Lake, Wisconsin. Verh. Int. Verein Limnol. 28:467-470.

Happy-Wood C (1988). Ecology of freshwater planktonic green algae. In: Sandgren C (ed). Growth and reproductive strategies of freshwater phytoplankton. Cambridge, pp. 175-226.

Hardin G (1960). The competitive exclusion principle. Science 131:1292-1298.
Jensen JP, Jeppensen E, Olrik K, Kristensen P, (1994). Impact of nutrients and physical factors on the shift from cyanobacterial to chlorophyte dominance in shallow Danish lakes. Can. J. Fish Aquat. Sci. 51:1692-1622.

Kotak BG, Lam AKY, Prepas EE (2000). Role of chemical and physical variables in regulating microcystin-LR concentration in phytoplankton of eutrophic lakes. Can. J. Fish. Aquat. Sci. 57:1584-1593.

Kruger GHJ, Eloff JN (1978). The effects of temperature on specific growth rate and activation energy of Microcystis and Snechococcus isolates relevant to the onset of natural blooms. J. Limnol. Soc. South. Afr. 4:9-20.

Lazorchak JM, Hill BH, Averill DK, Peck DV, Klemm DJ (2000). Environmental monitoring and assessment program-surface water: field operations and methods for measuring the ecological conditions of non-wadeable rivers and streams. EPA/620/R-00/007. US Environmental Protection Agency, Washington, DC.

Lepistö L, Holopainen AL, Vuoristo H (2004). Type-specific and indicator taxa of phytoplankton as a quality criterion for assessing the ecological status of Finnish boreal lakes. Limnologica 34:236-248.

Margalef R (1979). Perspectives in ecological theory. University of Chicago Press, Chicago.

Marti E, Aumatell J, Gode L, Poch M, Sabater F (2004). Nutrient retention efficiency in streams receiving inputs from wastewater treatment plants. J. Environ. Qual. 33:285-293.

Metcalf JS, Barakate A, Codd GA (2004). Inhibition of plant protein synthesis by the cyanobacterial hepatotoxin, cylindrospermopsin. FEMS Microbiol. Lett. 235:125-129.

Moss B, Mckee D, Atkinson D, Collings SE, Eaton TW, Gill AB, Harvey I, Hatton K, Heyes T, Wilson D (2003). How important is climate? Effects of warming, nutrient addition and fish on phytoplankton in shallow lake microcosms. J. Appl. Ecol. 40:782-792.

Oberholster PJ, Ashton PJ (2008). State of the nation: An overview of the current status of water quality and eutrophication in South African rivers and reservoirs. CSIR Report No. CSIR/NRE/WR/IR/2008/0075/C. Pretoria, p. 14.

Oberholster PJ, Botha AM, Cloete ET (2008). Biological and chemical evaluation of sewage water pollution in the Rietvlei Nature Reserve wetland area, South Africa. Environ. Pollut. 156:184-192.

Oberholster PJ, Botha AM, Cloete TE (2005a). An overview of toxic freshwater cyanobacteria in South Africa with special reference to risk, impact and detection by molecular marker tools. Biokemistri, 17: 57-71.

Oberholster PJ, Botha AM, Cloete TE (2005b). Using a battery of bioassays, benthic phytoplankton and the AUSRIVAS method to monitor long-term coal tar contaminated sediment in the Cache la Poudre River, Colorado. Water Res. 39:4913-4924.

Oberholster PJ, Myburgh JG, Ashton PJ, Botha AM (2010). Responses of phytoplankton upon exposure to a mixture of acid mine drainage and high levels of nutrient pollution in Lake Loskop, South Africa. Ecotoxicol. Environ. Saf. 73:326-335.

Padisák J (1985). Population dynamics of the freshwater dinoflagellate Ceratium hirundinella in the largest shallow lake of Central Europe, Lake Balaton, Hungary. Freshw. Biol. 15:43-52.

Pan Y, Stevenson RJ, Hill BH, Herlilhy AT, Collins GB (1996). Using diatoms as indicators of ecological conditions in lotic systems: a regional assessment. J. North Am. Benthol. Soc. 15:481-495.

Patrick R, Reimer CW (1966). The diatoms of the United States. Academy of Natural Sciences of Philadelphia, Philadelphia. 1:213

Peterson CG, Stevenson RJ (1989). Seasonality in river phytoplankton: multivariate analyses of data from the Ohio River and six Kentucky tributaries. Hydrobiologia 182:99-114.

Pollingher U (1988). Freshwater dinoflagellates: Growth, reproduction strategies and population dynamics. in: Sandgren, C., (ed)., Growth and reproductive strategies of freshwater phytoplankton. Cambridge, pp. 134-174.

Porra RJ, Thompson WA, Kriedemann PE (1989). Determination of accurate extinction coefficient and simultaneous equations for assaying chlorophylls $a$ and $b$ extracted with four different solvents: verification of the concentration of chlorophyll standards by atomic absorption spectrometry. Biochim. Biophys. Acta, 975:384-394. 
Premazzi G, Chiaudani G (1992). Ecological quality of surface water. Quality assessment schemes for European Community Lakes, EUR 14563 EN

Proulx M, Pick FR, Mazumder A, Hamilton PB, Lean DRS (1996). Experimental evidence for interactive impacts of human activities on lake species richness. Oikos 76:191-195.

Reynolds CS (1984). The ecology of freshwater phytoplankton. Cambridge Univ. Press, Cambridge, MA.

Reynolds CS, Huszar VLM, Kruk C, Naselli-Flores L, Melo S (2002). Towards a functional classification of the freshwater phytoplankton. J. Plankton Res. 24:417-428.

Robarts RD, Zohary T (1987). Temperature effects on photosynthetic capasity, respiration, and growth rates of bloom-forming cyanobacteria. N.Z.J. Mar. Freshw. Res. 21:391-399.

Scheffer M, Carpenter SR (2003). Catastrophic regime shifts in ecosystems: linking theory to observation. Trends Ecol. Evol. 18:648655.

Schelske CL, Rothman ED, Stoemer EF, Santiago MA (1974). Responses of phosphorus limited Lake Michigan phytoplankton to factorial enrichment with nitrogen and phosphorus. Limnol. Oceanogr. 19:409-419.

Schindler DW (1977). The evolution of phosphorus limitation in lakes. Science 195:260-262.

Schindler DW (1978). Factors regulating phytoplankton production and standing crop in the world's freshwaters. Limnol. Oceanogr. 23:478486.

Schulze RE (1997). South African Atlas of Agrohydrology and Agroclimatology. WRC Report No. TT 82/96. Water Research Commission, Pretoria, South Africa. p. 457.

Smith REH, Gosselin M, Taguchi S (1997). The influence of major inorganic nutrients on the growth and physiology of high arctic ice algae. J. Mar. Syskms, 11:63-73.

Smith REH, Kalh J (1983). Competition for phosphorus among cooccurring freshwater phytoplankton. Limnol. Oceanogr. 28:448-464.

Smith VH (1990). Phytoplankton responses to eutrophication in inland waters. In: Akatsuka I (ed.). Introduction to Applied Ecology. SPB, pp. 231-249.

SYSTAT (1997). Systat $\AA^{\circledR} 7.0 .1$ for Windows $\AA$ :Statistics. SPSS Inc., Chicago, Illinois, USA.

Takamura N, Otsuki A, Aizaki M, Nojiri Y (1992). Phytoplankton species shift accompanied by transition from nitrogen dependence to phosphorus dependence of primary production in Lake Kasumigaura, Jpn. Arch. Hydrobiol. 124:129-148.

Taylor R, Best HJ, Wiechers HNS (1984). The effluent phosphate standard in perspective; Part 1: Impact, control and management of eutrophication. IMIESA 9:43-56.
Taylor JC, Harding WR, Archibald CGM (2007). An illustrated guide to some common diatom species from South Africa. WRC Report, TT, 282/07. Pretoria: Water Research Commission, pp. 1-178.

Thornton JA, Walmsley RD (1982). Application of phosphorus budget models to South African man-made lakes. Hydrobiologia, 89:237245.

Toerien D (1977) A review of eutrophication and guidelines for its control in South Africa. CSIR Special Report. WAT 48.

Truter E (1987). An aid to the identification of the dominant and commonly occurring genera of algae observed in some South African impoundments, Department of Water Affairs, Private Bag x313 Pretoria, South Africa, ISBN $062111510 X$, pp. 1-97.

US EPA (1996). Environmental Indicators of Water Quality in the United States (US EPA 841-R-96-02). Office of Water (4503F), US Government Printing Office, Washington, DC.

Van Dam H, Mertens A, Sinkeldam J (1994). A coded checklist and ecological indicator values of freshwater diatoms from the Netherlands. Netherlands J. Aquat. Ecol. 28:117-133.

Van Vuuren S, Taylor JC, Gerber A, Van Ginkel C (2006). Easy identification of the most common freshwater algae. - North-West University and Department of Water Affairs and Forestry, Pretoria, South Africa, pp. 1-200.

Walmsley RD, Butty M (Eds) (1980). Limnology of some selected South African impoundments. A collaborative report by Water Research Commission. National Institute of Water Research, CSIR, South Africa. Pretoria.

Watson SB, McCauley E, Downing JA (1997). Patterns in phytoplankton taxonomic composition across temperate lakes of different nutrient status. Limnol. Oceanogr. 42:487-495.

Werner D (1977). Silicate metabolism. in: Werner D (ed). The Biology of diatoms, University of California Press, pp. 110-149.

Willen E (1991). Planktonic diatoms-an ecological review, Stuttgart, August 1991. Algol. Stud. 62:69-106.

Willen $E$ (2000). Phytoplankton in water quality assessment-An indicator concept. In: Heinonen P, Ziglio G, Van der Beken A (Eds.). Hydrological and limnological aspects of lake monitoring., John Wiley \& Sons, LTD, New York, Toronto, Brisbane, pp. 58-80.

Withers PJA, Jarvie HP (2008). Delivery and cycling of phosphorus in rivers: A Review. Sci. Total Environ. 400:379-395. 